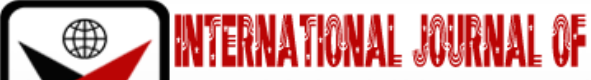

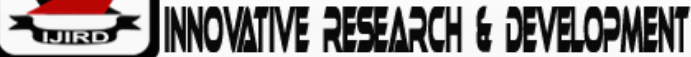

ISSN 2278-0211 (Online)

\section{Effectiveness of Total Quality Management on Organisational Performance: Case Study of Printing Press in Kumasi, Ashanti Region, Ghana}

Emmanuel Kwadwo Opoku
Assistant Registrar, Department of Public Relations Directorate,
Kumasi Technical University, Ghana
Anthony Kofi Badu
Senior Lecturer, Department of Public Relations Directorate,
Kwame Nkrumah University of Science and Technology, Ghana
Kwamena Kurefi Edonu
Assistant Registrar, Department of Public Relations Directorate,
University of Mines and Technology, Ghana

\begin{abstract}
:
Anecdotal evidence suggests that low quality images, spelling mistakes, poor leading, poor choice of typography, inconsistency in colour profiling and incorrect choice of file formats have resulted in poor output of printed works in the print firms in Kumasi. The study was to evaluate the effectiveness of Total Quality Management in the Ghanaian printing press. The descriptive survey approach was used to describe the total quality management on organisational performance on printing firms in Kumasi, Ghana. Primarily, data was gathered from 15 management personnel and 135 workers. A total of 150 respondents answered questions through self-administered questionnaire. The results showed that people's involvement or employees' participation in quality practices is management's responsibility which is the centre of attention. Also, effectiveness of Total Quality Management includes three components, namely management focus, employee focus and customer focus and these must not be practiced in isolation. The study recommended expediency on the part of management to train employees to be empowered to perform even in the absence of top management.
\end{abstract}

Keywords: Total quality management, printing industry, print quality, kumasi metropolis, Ghana

\section{Introduction}

This paper focuses on the effectiveness of Total Quality Management on Organisational Performance of the printing firms in Kumasi in the Ashanti Region of Ghana. Like other industries, the printing industry plays a major role in the economy of Ghana. The printing press creates an extensive variety of items which are needed in almost every progression of our normal life. These include books, magazines, memo pads, newspapers, post cards, and many others (Deshpande, 2011). In the Printing press, however, one of the key factors customers consider when buying or upgrading a colour reproduction system is quality (Engeldrum, 2004). Nonetheless, 'Quality' however is a dynamic idea that applies to every facet of life. Presently, the world depends on higher levels of excellence. This is why the idea of 'quality management' is frequently viewed as the foremost need for any organisation that aspires to be successful (Cornelison, 2013).

With quality in mind as the driving force for continuous perfection in the print industry, a vast array of theories and philosophies have been propounded on quality and quality management standards by prestigious scholars such as Philip Crosby, William Deming and Joseph Juran. Moreover, in the advanced countries, Quality Management Systems such as Lean Manufacturing, Six Sigma, Deming Prize, International Organisation for Standardisation(ISO) etc. have been implemented in organisations and have proved to be sensational. A typical example is an extensive study conducted by Cornelison in 2013 using some selected printing presses in California as a case.

However, there is difficulty in the application of the 'various theories and philosophies on quality and quality management' (Cornelison, 2013) in organisations in Ghana particularly the printing industry. For the printing industry in Ghana to have a better opportunity in future, there should be proper identification of all the components of print quality management system to ensure the maintenance of 'quality' advantages in the services rendered to customers.

It is believed that the quality of printed materials has considerable impact in information communication. A quality printed material attracts the interest of the target audience. A quality book or publication makes reading pleasurable. There are many factors that affect the quality of publications at the prepress level. These include spelling mistakes, poor leading, poor choice of typography, low quality images, inconsistency in colour profiling and incorrect choice of file 
formats. The absence or the adoption of ineffective quality management practices to some extent affect the output of the printed materials. It has been discovered that the poor quality of publications and other visuals starts from the designing section. The designer is expected to take into consideration elements of design such as shapes, colour and lines; principles of design such as balance and unity; and page elements for the publication being designed (Palacio and Vit, 2011). If the designers neglect or fail to apply these basic principles and elements of design in any publication, the quality of that publication will be substandard. This will affect the patronage of the publication leading to loss of clients/profits.

Therefore, quality plays a critical role in client satisfaction, effective information communication and attraction of target audience(Palacio and Vit, 2011). Lack of quality management practices in any of the sections in the production line will not produce a good job that will meet the clients' expectation. This will make the client unhappy with the job. Once quality management practices are effectively implemented, a good job will be done, which will meet the expectation and satisfaction of the client.

Anecdotally, printing firms that lack well-structured organograms in Ghana may face many problems. For instance, in the Kumasi Metropolis, printing firms within Asafo are largely concentrated in about 50 metres range of each other and may operate in a similar business. Some firms within the vicinity also sell stationary, bind books and perform other services related to printing. As such, Asafo is considered as the hub of pre-press activities in the Metropolis with some of their designs being substandard. Since most of the employees work under the supervision of the owners or managers who may lack formal education and training in pre-press, problems such as typographic errors, low quality images, inappropriate page design/typesetting and poor choice of file format, among many others, may be problems facing these firms. These may further result in poor print outputs from these firms in Kumasi.

Recent evidence shows that these design firms located at Asafo contribute significantly to the growth of the graphic reproduction industry in Kumasi. Therefore, quality management issues affecting these firms would have consequential effect on the industry. There seems to be limited information, however, pertaining to their influence and impact on society with regards he to how these problems affect them. This necessitates therefore this inquest into TQM practices and their effectiveness on organisational performance in the print industry in Kumasi.

It has been discovered that the poor quality of publications and elements of design such as line, shape, texture and many others start from the design stage (Cornelison, 2013). Quality design must radiate aesthetic appeal and be functional as well however, it has been observed by the researcher that most designs from Ghanaian printing firms deviate from practical functionality and focuses more on aesthetism neglecting the standards and principles that guide quality design. The only way to increase the quality of the print products is for print firms to adopt quality design management practices. Prominent among them is the Total Quality Management (TQM).

Machines and technology may, in one way or the other, contribute to the poor quality of printed materials even in the face of modern technology. If quality management practices are not integrated into the print industrial processes, the survival of the industry will be in jeopardy.

\section{Objectives of the Study}

The study is aimed at:

- To examine the extent of people involvement in TQM variables practiced in the printing industry in Ghana.

- To identify the factors that inhibit the practice of TQM in the firms of printing industry in Ghana.

\section{Review of Related Literature}

\subsection{Total Quality Management}

The concept of 'Total Quality Management' (TQM) may have been applied to a number of industries for nearly a century now. This application of TQM in such companies within the printing industry (like Type Company Ltd., Buck Printing Press, Gerofix Rent-A-Sign Ltd among others) has improved organisational performance. This term, TQM, is distinctively modified to suit most needs of organisational goals, which has implemented such a system. Moreover, TQM is used differently by organisations, and as such, it should conform to the concepts so as to fit the organisation's goals.

Quality Management (QM) has a very close link with the manufacturing surroundings. At present, most definitions and practices of quality came from the 'manufacturing and object-based economy' (Hough, 2004).

Before the advent of the theory of TQM, a great deal of work had been done in the field of quality movement. All these were meant to respond to the keen global competition and also to deliver quality products or services to clientele. According to Dale et al., (1994) explained quality movement as 'quality control, inspection, TQM, and quality assurance'. This move has kept pace beside the varying trade. Kulkarni, (2005) stated that, TQM is a wide energetic process for facilitating a constant progress in the adequacy and productivity of all aspects of a business. It unites capacities and procedures within the entity for it attains a constant progress in the delivery of quality goods and services.

According to Talha (2004), Total Quality Management (TQM) brings together the ideas of 'product quality, process control, quality assurance and quality improvement' thus it makes it a powerful Quality Management (QM) system. More leaders are now concentrating on quality to enlarge effectiveness, lessen charge, and meet client demands. These leaders are now getting to comprehend the significance of always getting a better quality of their services and products in order to achieve these goals.

A fundamental factor that is usually considered before choosing or buying a specific product or service is the quality of the product or service. As most business entities are trading internationally, one of the approaches to ensure productive trade is to give excellent services and quality goods in a particular market in order to bring satisfaction to the customer (Bendellet. al.,1995). Yeung and Armstrong (2005) opined that quality is an inherent feature of commercial 
services and merchandises. Consumers, usually, are pleased with the delivery of quality goods and services (Walsh et al,, 2002). Japan was able to capture, maintain and construct market share using'superior quality'. This makes suppliers of inferior products and poor services unlikely to make it in the coming days (Bendellet al., 1995).

\subsection{Printing Technologies in the Printing Industry in Ghana}

The printing industry in Ghana uses diverse printing technologies to print business documents, books, catalogues, forms, magazine, newspapers, etc. These technologies include flexography, letter-press, lithography, rotogravure, screen, and digital technologies including electro-photography and inkjet. As a matter of fact, the machinery is used based on the quality of print required, number of impressions needed, the available resources, the equipment cost, per unit cost of consumables use of variable content, and other factors (Romano, 2004).

\subsubsection{Overview of Offset Lithographic Printing}

In lithography, the plate is planographic, the image areas are grease-receptive and water-repellent,while the non-image areas are water-receptive. Both water and oil-based ink isapplied to the plate. The water wets the non-image areas of the plate and prevents the ink from wetting those areas. Ink transferred to the image areas is subsequently transferred toa rubber covered blanket cylinder (offset) that in turn transfers the image to the substrateunder high pressure. The inks used are relatively thick and viscous in comparison with flexoand gravure. In sheet-fed standard screen rulings are increasing, with $175 \mathrm{dpi}$ the norm and 200 or $250 \mathrm{dpi}$ common (Romano, 2003).

The current world of printing process is dominated by the offset lithographic printing, especially in the United States of America. Research by A. F. Lewis and Co., which specialises in market research within the graphic arts industry, estimates that out of the over 53,000 organisations employed in the printing process, approximately 49,000 of them make use of the lithographic press. Based on this, it can be concluded that lithographic printing may remain a feasible technology in 'the long term for static, long run jobs either as a standalone technology or as a component of hybrid production' (Romano, 2003). This has been vilified as digital printing has expanded printing in Ghana.

\subsubsection{Types of Lithographic Printing}

Lithographic printing has three distinct sub-processes, including heat set web offset, non-heat set web offset, and sheet fed offset. Sheet-fed presses are the presses which are tailored to print single sheets of paper at a time by picking single sheets of paper out of a feed table. The operation is such that it delivers sheets evenly, 'one at a time down a feed board to the printing unit' (Appiah, 2002). It is important to note that the numerous presses offering offset lithographic printing services are sheet-fed presses.

The web offset presses are called by this name because they use 'rolls of paper which are continuously fed into the press'. Incidentally, little of lithographers make use of the web offset process. The heat-set 'web offset printing' which uses dried ink that circulates in a hot air system is extremely helpful 'for high-volume, high-speed production runs (up to 40,000) impressions per hour'.

\subsection{Evolution of Total Quality Management (TQM)}

Total Quality Management (TQM), being a key management issue in organisations, evolved as a result of increased levels of competition in the global market.

Powell (1995) points out that: 'TQM's roots can be traced to 1949, when the Union of Japanese Scientists and Engineers formed a committee of scholars, engineers, and government officials dedicated to enhance Japanese productivity, and improving their post-war quality of life' and 'American firms began to take serious notice of TQM around 1980.' All the same, the researcher argues that numerous of the TQM dimensions were being applied by organisations before the TQM movement appeared; hence, it difficult to trace the exact time of inception of the term TQM. Stuelpnagel (1993) states that the source of TQM in Ford and Crowter's book, 'My Life and Work', published in 1926. It is however obvious that the term and philosophy of TQM appeared at about the mid 80's. Bemowski (1992) states that the term TQM was first used in 1985 by the Naval Air Systems Command to portray its Japanese-style management approach to quality growth.

It is likely that the term Total Quality Management (TQM) came to substitute the formerly used term Total Quality Control (TQC), with the word 'control' being replaced with 'management', in order to manage and control quality. This is reinforced by the view held by Deming (1982) that sampling inspection needs to be suppressed. The term 'control' is occasionally taken to mean command above the activities of workforces. This is obviously not the purpose of TQM (Godfrey et al., 1997). For instance, in USA, the growth of quality management system came out of the impact of its markets by products of Japan which started in the 70s. This was in addition with the impact of the writings by Crosby, Deming, Feigenbaum and Juran. Firms and scholars studied the works of these and other authors such as Ishikawa and integrated their procedures with quality management to eventually bring about the concept of TQM. This movement drifted within other nations with the UK being among the first.

In the 1981, Dale was the first scholar to begin research in quality management, and even accepted that TQM came from the UK as a result of the activities of the Department of Trade and Industry National Quality Campaign which began operations in 1983. This was notwithstanding the starting work of firms including IBM. He describes a talk he had with John MacDonald (one of the stalwarts of the UK quality administration framework and the principal Managing Director of Crosby Associates UK Ltd) who suggested that pretty much the mid 1986 he was utilising the term TQM in his CrossAtlantic correspondence with Philip Crosby where Crosby replied to the answer, 'What is TQM?' It is additionally important to specify that in the introductory part of the mid 80s the utilisation of value related terms and acronyms was 
not as it is today. The TQM programme still seems to continue to sustain its strong presence in a lot of public organisations of contemporary days (Van Seaton, 2010).

\subsection{Factors that Influence TQM}

Adopting a TQM programme depends largely on the effective implementation of certain quality management practices by institutions. Fewer defects, reduced rework and scrap, lower stock levels, decreased lead times, higher flexibility and expanded employee fulfilment are reportedly among the benefits of an effective TQM programme (Sirota 1994, Rhonda, Reger, Gustafson, DeMarie and Mullane 1994). What is crucial is a thorough understanding of the barriers that can impede an effective quality change. There is ample confirmation that quality management systems enhance institutional execution if correctly applied (Salegna and Fasel 2000). On the other hand, the conflicting track record of institutions answered to have implemented TQM, has brought about many discussions about the usefulness of TQM programmes. It points out that the majority of failures include the procedure by which the TQM philosophy is implemented instead of flaws in the values of TQM itself. There seems to be multitude explanations says Mani, Murugan and Rajendran (2003) and Salegna and Fasel (2000) why institutions cannot perform in their endeavours to execute a quality management system; however, two common difficulties seem to be a lack of strategic planning and an absence of a proper culture understanding of TQM programmes.

So as to analyse Total Quality Management (TQM), it is significant to know the reasons why TQM programmes come up short, which may give insight into the significance to know the meaning of TQM. Institutions and authors have distinguished variety of reasons why TQM programmes come up short and numerous reviews have been done on this subject (Grib, 1993). The following is a rundown of obstacles, barriers, reasons and pitfalls institutions have reported when executing TQM (Djerdjour and Patel 2000; Grib 1993; Macdonald 1992; Tamini and Sebastianelli 1998). Understanding the obstacles that can hinder the success of TQM initiatives is crucial for the existence of TQM programmes. The barriers cited to this research can be used with other TQM frameworks.

What is of greatest significance is the interconnectedness and communication between the remedies of the gurus' different principles, i.e., their systemic nature which ought to strengthen each other and form a synergistic, comprehensive strategy towards TQM.An analysis of the TQM programme clearly shows that more and more institutions are developing self-evaluation models as a tool to inspire employees' empowerment and obligation for the TQM programme. As institutions make use of TQM, self-evaluation models are adopted in the earlier stages to distinguish change opportunities and design for their execution. However, for efficiency of TQM international self-appraisal models can also be incorporated by institutions to measure their TQM progress.

\subsection{Concept of Total Quality Management (TQM)}

TQM is a set of skills and approaches that help to prevent variation from a production process or service-delivery system to enhance efficiency, reliability, and quality (Steingard and Fitzgibbons, 1993). It puts together all fundamental management skills, existing growth efforts, and technical tools through an orderly procedure which is concentrated on continuous improvement (Barton, 2003). Kanji and Asher (1996) assert that TQM is a regular method of improvement for individuals, groups of people, and whole firms. it comprises of four principles (delight the customer, management by fact, people-based management, and continuous improvement) and eight major concepts (customer satisfaction, internal customers are real, all work is process, measurement, teamwork, people make quality, continuous improvement cycle, and prevention). Vuppalapatiet al., (1995) claims, TQM is an integrative philosophy of management for constant improvement of the quality of products and processes to attain customer satisfaction. It is believed that once a business repeats it is very likely to grow. This repetitive business depends on the customer. When the needs of the customer are properly met it is very likely to retain them and even make more. That is why TQM puts more premium on customer satisfaction.

Though Total Quality Management (TQM) and conventional quality management emphasise quality, the concepts and principles employed by TQM vary from that of the traditional quality management. This is what makes it a modern management tool. Paraphrasing Gaither (1994), conventional quality management pays attention to delivery of quality output through thorough inspection. Many criticisms have been made against using this approach; a typical example being the decision on the number of products that must be inspected; what must be done to defective products detected during inspection and the level to which meticulous inspection may ensure the delivery of quality service or product to the customer. Despite this, it must be noted that oversight may occur during inspection. Kulkami (2005) claims that TQM measures are not strictly tied to traditional rejects, reworks, downgrades and the likes as in traditional quality management. Consequently, TQM brands traditional quality management as being costly.

Traditional quality management curtails the duty of quality delivery to a department rather than making it the responsibility of the whole company (Benowits, 2001). To Talha (2004), TQM covers a wide spectrum of management and control processes which are meant to concentrate on the whole organisation and all its workers in offering products or services to the satisfaction of the customer. It engages tools and techniques that see to the unique quality achievement. TQM is observed as partly philosophical and partial practice-oriented (Yeung and Armstrong, 2005). It needs experienced minds as well as technical knowledge in the collection and analysis of information to offer results that could upgrade the competitive advantage of the organisation (Dale and Oakland, 1991).

\section{Research Methodology}

This study employed quantitative method with descriptive survey strategy.According to Lancaster (2005) a questionnaire can be used as a data collection instrument to elicit information from individuals or target population through a survey research design. A self-administered questionnaire was used. Two set of questionnaires were structured 
for this study: one, for top management level and the second, for non-management level. These questionnaires were administered to those in managerial positions and non-management level. The 5-point Likert scale closed-ended questions aided the researcher to collect and analyse the data.

Printing firms in Kumasi constituted the population of a study. The sample size of 150 was drawn from selected printing firms in Kumasi, Ashanti Region. Purposive sampling was used to select 15 printing firms in Kumasi. The data was analysed with descriptive and inferential statistical tools (regression analysis and frequencies) with the aid of Statistic Package for Social Sciences (SPSS) software. The results were presented in tables and discussion form.

\section{Data Analysis and Discussions}

\subsection{Profile of Respondent Firms}

The management questionnaire of the types of printing firms indicated that $82 \%$ of the data were obtained from general printing firms, $12 \%$ from advertising printing firms and 6\% from packaging printing firms (see figure 1). The data on the operation experience of the respondent firms yielded the following: $6.7 \%$ for companies that are within the range of 6-10 years, $53.3 \%$ for companies that are within the range of $11-15$ years, $26.7 \%$ for companies that are within the range of $16-20$ years, $13.3 \%$ for companies that are above 21 years. This is a sign that majority representing $53.3 \%$ of the printing industry have appreciable period of operation experience (see Table 1).

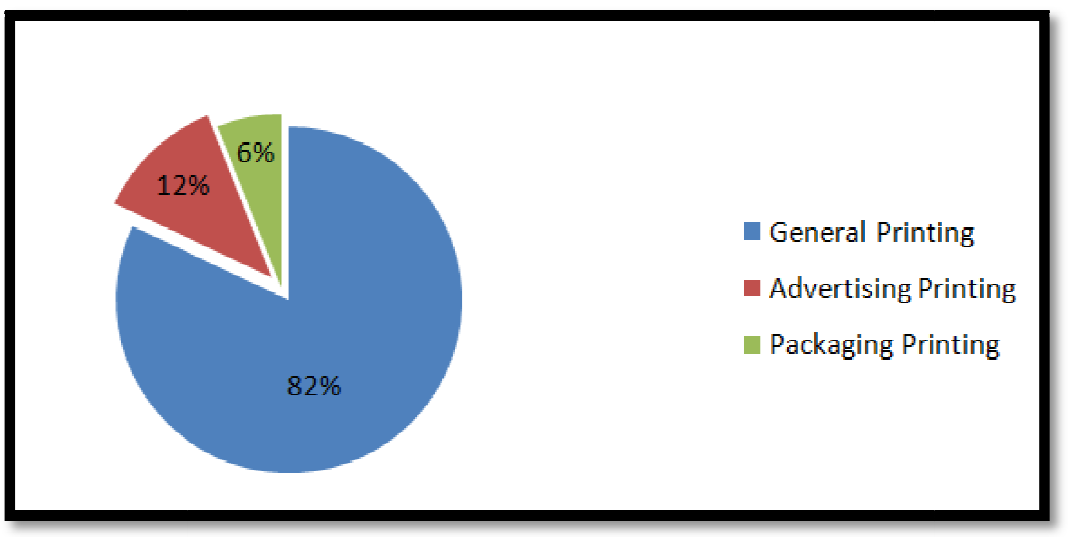

Figure 1: Types of Printing Firms

\begin{tabular}{|c|c|c|c|c|c|}
\hline \multirow{3}{*}{ Valid } & Frequency & Percent & $\begin{array}{c}\text { Valid } \\
\text { Percent }\end{array}$ & $\begin{array}{c}\text { Cumulative } \\
\text { Percent }\end{array}$ \\
\hline & 6-10years & 1 & 6.7 & 6.7 & 6.7 \\
\cline { 2 - 6 } & 11-15years & 8 & 53.3 & 53.3 & 60.0 \\
\cline { 2 - 6 } & 16-20years & 4 & 26.7 & 26.7 & 86.7 \\
\cline { 2 - 6 } & Above & 2 & 13.3 & 13.3 & 13.3 \\
\cline { 2 - 6 } & 21years & & & & 100.0 \\
\hline
\end{tabular}

Table 1: Number of Years in Operation Experience Field Data: 2020

\subsection{Leadership}

Leadership is the skill to motivate confidence and support among those required to attain organisational goals (DuBrin, 1995). Anderson et al., (1994) describe the concept of leadership as the ability of top management to build up, practice and lead a continuous vision for the firm, driven by changing client requirements, as opposed to an internal management control role. Filleyet al.,(1976) indicated that management needs to cooperate with worker's decision making. It is believed that workers are more expected to agree and implement a decision they participated in. To ignore the suggestions of the employees disheartened them and created barriers between management and employees. Getting the best out of them becomes difficult. This attitude is not conducive to TQM programmes. Leadership is not about controlling. To Juran and Gryna (1993), exact roles of top management can be discovered as: Build up quality policies, establish and deploy quality goals, provide resources, provide problem-oriented training, and stimulate development. For this to be successful, management need to establish excellent relationship with the employees to get them on board for a common goal. That is one reason why employee empowerment and development remain essential in TQM programmes. But this research has discovered that less priority has been given to employee empowerment and improvement as an outcome of management's inability to represent the decision of quality, process or product conformance to the employees.

\subsection{Top Management Commitment}

From the table 2 below, majority of the respondents point out that they have interest in long term business success. Management believed that to retain and build more clientele, an overall vision of the firm as expressed by top management should be of higher standard that would be appreciable to all (Table 2). Moreover, 11 managers agreed, 3 
strongly agreed to be interested about long term business success with the remaining manager being Neutral on the question.

\begin{tabular}{|c|c|c|c|c|c|}
\hline & & Neutral & Agree & Strongly Agree & Total \\
\hline Management is interested & & 1 & 11 & 3 & 15 \\
\cline { 2 - 6 } $\begin{array}{c}\text { In long term business } \\
\text { success }\end{array}$ & & & & \\
\cline { 2 - 6 } & & & & & \\
\hline Total & 1 & 11 & 3 & 15 \\
\hline
\end{tabular}

Table 2: Management Is Interested in Long Term Business Success

Field Data: 2020

To paraphrase Rahman and Siddiqui (2006), the success achieved in implementing TQM is strongly dependent on the commitment of top management towards the achievement of organisational goals because they are the key policy makers of the firm.

However, study disclosed that TQM programme does not receive a lot of commitment from top management. The provision of the right logistics for certain jobs are being compromised and other materials that may not yield the perfect result are used instead. For example, laser films are used to print instead of the image setter films which have the potential to produce high quality output than the laser film.

\begin{tabular}{|c|c|c|c|c|c|}
\hline & & Disagree & Neutral & Agree & Total \\
\hline $\begin{array}{c}\text { Management is critical } \\
\text { about quality output of } \\
\text { print materials }\end{array}$ & & 1 & 3 & 11 & 15 \\
\cline { 2 - 5 } & & & & & \\
\hline Total & 1 & 3 & 11 & 15 \\
\hline
\end{tabular}

Table 3: Management Is Critical About Quality Output of Printed Materials

Field Data: 2020

Inferring from the table 3 above, the researcher sought to find out management's quality output of printed materials. Conversely, 11 managers were critical about quality output of print materials whiles 3 managers remained neutral and 1 disagreed.

\subsection{Quality Policy}

Majority of the respondents indicated that they have the notion of quality captured in their slogan, vision or mission statement. This is ensured through verbal instructions and job instruction cards among others. Beheshti and Lollar (2003) stated that quality policy is a strategic working policy that gives room to a firm to answer to expanding competition and developing client expectations. This indicated that the policy must be reviewed and updated periodically depending on consumer expectations among others. However, findings revealed that most printing houses that has quality policy do not review the policy periodically in accordance with the ever-changing needs of business environment and the customers. Effective TQM practices could be achieved if quality policy is consistent with TQM concepts.

\subsection{Employee Involvement}

Contribution is decisive in motivating action on quality management (Juran and Gryna, 1993). Total involvement puts together all concepts in quality management, including the participation and input of all members (from shop floor employee to senior managers) to continuous improvement (Dimitriades, 2000). In an effective TQM environment, all employees are allowed to participate in achieving organisational goals. However, findings revealed that majority of the respondents representing $40.1 \%$ strongly disagree when the respondents' opinion was sought on the level of agreement to the statement 'Employees are keenly included in quality activities and policy creation'. 2.2\% disagreed, $12.6 \%$ was neutral on the level of agreement, $29.6 \%$ agree whereas $14.8 \%$ strongly agree (Table 4 ) below.

Findings also disclosed that due to passive participation of employees in quality activities and policy creation, they are reluctant towards the implementation of the quality policies developed by management because they are of the view that they are demoralised when such decision is made without their contribution. They also expressed they feel satisfied when their suggestions are acted upon and instead of encouraging and raising their morale, they do not receive any incentives in return and that affect their effective participation. 


\begin{tabular}{|c|c|c|c|c|c|}
\hline Employee Involvement & $\begin{array}{c}\text { Strongly } \\
\text { Disagree }\end{array}$ & Disagree & Neutral & Agree & $\begin{array}{c}\text { Strongly } \\
\text { Agree }\end{array}$ \\
\hline $\begin{array}{c}\text { Employees are actively } \\
\text { involved in quality } \\
\text { activities }\end{array}$ & $55(40.1 \%)$ & $3(2.2 \%)$ & $17(12.6 \%)$ & $40(29.6 \%)$ & $20(14.8 \%)$ \\
\hline $\begin{array}{c}\text { Quality management } \\
\text { activities are as joint } \\
\text { effort }\end{array}$ & $16(11.9 \%)$ & $10(7.4 \%)$ & $4(3.0 \%)$ & $55(40.1 \%)$ & $50(37.0 \%)$ \\
\hline $\begin{array}{c}\text { Management acts on } \\
\text { employee's suggestion }\end{array}$ & $5(3.7 \%)$ & $35(25.9 \%)$ & $5(3.7 \%)$ & $40(29.6 \%)$ & $50(37.0 \%)$ \\
\hline $\begin{array}{c}\text { Quality awareness } \\
\text { education is given to } \\
\text { employees }\end{array}$ & $60(44.4 \%)$ & $16(11.9 \%)$ & $10(7.4 \%)$ & $4(3.0 \%)$ & $45(33.3 \%)$ \\
\hline $\begin{array}{c}\text { The firm has employee } \\
\text { development programme } \\
\text { in place }\end{array}$ & $70(51.9 \%)$ & $10(7.4 \%)$ & $2(2.2 \%)$ & $35(25.9 \%)$ & $1712.6 \%)$ \\
\hline
\end{tabular}

Table 4: Employee Involvement

Field Data: 2020

\subsection{FaultsObstructing the Practice of TQM And How to Rectify The Flaws}

To examine the possible faults that inhibit the practice of TQM programmes and how to rectify these flaws, opinions of the respondents are computed in table 5 below.

\begin{tabular}{|c|c|c|}
\hline $\begin{array}{c}\text { Faults in the practice of Quality Management } \\
\text { System }\end{array}$ & $\begin{array}{c}\text { Frequenc } \\
\mathbf{y}\end{array}$ & Percentage \\
\hline Less participation of employees in decision making & 35 & $25.9 \%$ \\
\hline Lack of education and training for employees & 50 & $37.0 \%$ \\
\hline Less trust amongst employees for senior members & 35 & $25.9 \%$ \\
\hline Lack of Inter Institutional Communication & 15 & $11.1 \%$ \\
\hline Total & 135 & $100 \%$ \\
\hline
\end{tabular}

Table 5: Faults in the Practice of Quality Management System

Field Data: 2020

There are many things in management practices that inhibit the development of an organisation. Out of the lot respondents were asked to rate on some few faults. 35 respondents representing $25.9 \%$ indicated that less participation of employees in decision making affected the development of quality while 50 repondents representing $37.0 \%$ agreed that absence of education and training for employees were great faults in the development of quality management systems. Moreover, 35 and 15 respondents respectively representing 25.9\% and $11.1 \%$ also indicated that less trust amongst employees for senior members and lack of Inter Institutional Communication were faults in the development of quality management systems.

\subsection{Rectification of Flaws in the Practice of TQM}

Table 6 below shows the response of respondents on how to rectify flaws in quality management systems. 33.3\% show respondents attested to using supervision and monitoring to rectify flaws with $11.1 \%$ going for employee involvement in quality management systems. $22.2 \%$ advocated for training and education whiles $29.6 \%$ entreated strong motivation for employees.

\begin{tabular}{|c|c|c|}
\hline How to rectify flaws in Quality Management Systems & Frequency & Percentage \\
\hline Supervision and Monitoring & 45 & $33.3 \%$ \\
\hline Employees involvement in quality management systems & 15 & $11.1 \%$ \\
\hline Institution of checks and balances in the organisation & 5 & $3.7 \%$ \\
\hline $\begin{array}{c}\text { Contitnuous training and education on quality } \\
\text { management systems }\end{array}$ & 30 & $22.2 \%$ \\
\hline Strong motivation for employees in organisation & 40 & $29.6 \%$ \\
\hline Total & 135 & $100 \%$ \\
\hline
\end{tabular}

Table 6: How to Rectify Flaws in the Practice of TQM

Field Data: 2020

Management is also of the opinion that lack of understanding of Total Quality Management is one of the key obstructions to the practice of TQM as indicated in Table 7 below: 


\begin{tabular}{|c|c|c|c|c|}
\hline Variable & Frequency & Percent & $\begin{array}{c}\text { Valid } \\
\text { Percent }\end{array}$ & $\begin{array}{c}\text { Cumulative } \\
\text { Percent }\end{array}$ \\
\hline $\begin{array}{c}\text { Absence of Understanding of Total } \\
\text { Quality Management }\end{array}$ & 13 & 86.7 & 86.7 & 86.7 \\
\hline $\begin{array}{c}\text { Absence of employee involvement in } \\
\text { decision making }\end{array}$ & 2 & 13.3 & 13.3 & 13.3 \\
\hline Total & 15 & 100.0 & 100.0 & 100.0 \\
\hline
\end{tabular}

Table 7: Obstruction to the Practice of Total Quality Management

Field Data: 2020

According to the managers sampled, they are keen to taking away all barriers that inhibit quality management (see Table 7 above, researchers' fieldwork, 2015). So, the researcher sought to find out the possible obstruction to quality management. From the managers' view, two basic things inhibit the progress of Quality Management. They lack understanding of total quality management and absence of employee involvement in decision making.

Majority of managers, that is $86.7 \%$, went in for lack of understanding of total quality management while $13.3 \%$ went for absence of employee involvement in decision making. As such more education and training must be given to employees to enable them to know, understand and use the practices of quality management.

\subsection{TQM practices improvement on General Performance in the Printing Industry}

Managers' responses to the question, whetherthe practice of TQM improves the general performance and growth of their firm,from the figure 2 below, all managers agreed with the researchers' assertion that the practice of Total Quality Management improves the general performance and growth of companies. And therefore, it is very effective.

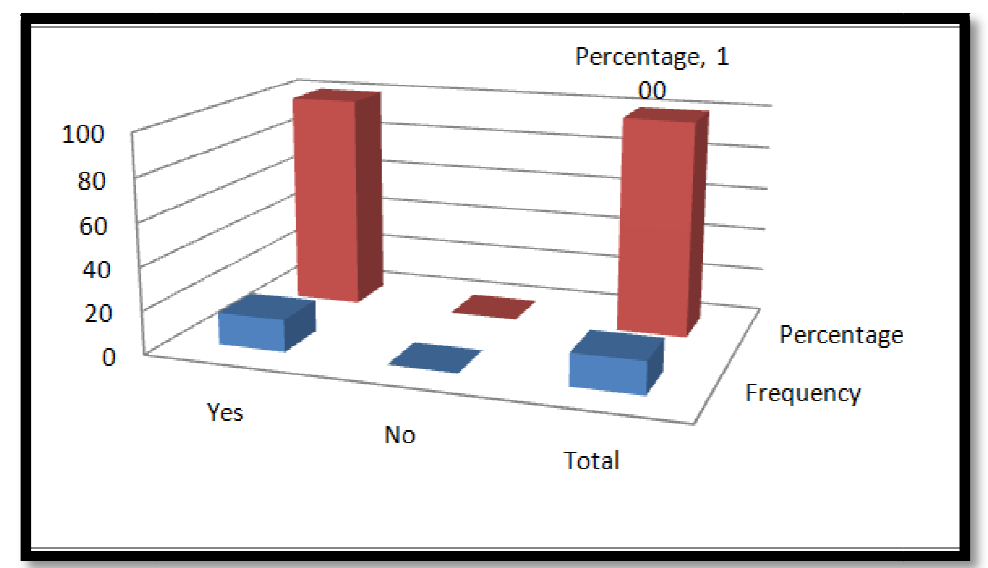

Figure 2: Effective of TQM Practice on Improvement of General Performance and Growth in Printing Firm

\section{Conclusions}

This study examined the effectiveness of TQM in the printing industry and how it impacts on organisational performance. It is evident that the achievement of TQM programmes is dependent on the collaborative effort by management and employees. Failure on the part of any of the parties involved affects the effectiveness and success of the TQM programme.Taking a critical look at TQM components, specifically management focus; it stressed on leadership, total management commitment and good clearly defined policy. However, findings revealed that managers in the printing industry demonstrate some level of leadership but that is not enough to constitute effective leadership as some managers centralise all activities on themselves when they can equally delegate.

All managers showed interest in quality but their commitment to ensuring quality is not the best as management does not make resources available and sometimes use substandard material for certain jobs. These go a long way to affect the final output. They have quality policies that are captured in slogans, visions and job instruction cards. Management commitment is expressed orally without taking steps to ensure its practice. Research revealed that employee participation is very important to the achievement of TQM programmes that is why employees are allowed to suggest. However, their suggestions are often ignored and that demoralise them. Even when their suggestions succeed in increasing efficiency, they do not receive any incentive to raise their morale.

\section{Recommendations}

- Management must commit itself by providing resources and facilities such as funds to support employees training and education to enable them to always do things right the first time and as captured in Philip Crosby's approach. Employees' education and training are prerequisite to employee empowerment and total participation by all stakeholders helps to realise the full benefit of TQM programmes.

- Management must provide the right logistics for the job since this goes a long way reflect in the final output. 
- Management must adopt effective leadership style. Decisions relating to quality should not be restricted to only few employees since this attitude of management has the tendency to raise division among workers and consequently lead to apathy.

- Pragmatic roles must be taken by management to ensure consistent review of the company's quality policy and action strategies needed to achieve set organisational goals and objectives.

- Recognition and rewards play a significant role in motivating employees in TQM programmes. Printing firms must institute reward systems for effective suggestions, commitment to implementing quality programmes according to specifications and general performance in the TQM programme.

- A system of information collection from the customers must be established. Oakland (2005) pointed out that quality begins with the understanding of client needs and ended when those needs were fulfilled.

\section{References}

i. Barton, A. (2003). The department of defence-Australia's most profitable business?Australian Accounting Review, 13(30), 35-40.

ii. Beheshti, H. M., and Lollar, J. G., (2003). 'An empirical study of US SMEs using TQM', Journal of TQM and Business Excellence, Vol. 14, No. 8, pp. 839-847.

iii. Bendell, T., Penson, R., and Carr, S., (1995). 'Illuminate: the quality gurus-their approaches described and considered', Managing Service Quality, Vol. 5, No. 6, pp. 44-48.

iv. Benis, W., and Nanus, B., (1985). Leaders. New York: Harper and Row.

v. Bemowski, K., (1992). 'The Quality Glossary', Quality Process, 25(2), 18-29.

vi. Benowitz, E. A., (2001). Cliffs Quick Review: Principles of Management, Hungry Minds, New York, NY.

vii. $\quad$ Besterfield Dale H. (2011). Total Quality Management, (Revised Edition). Pearson Education India.

viii. Cornelison, P., (2013). 'The Effectiveness of Total Quality Management Principles in the Printing Industry', USA.

ix. Dale, B., and Oakland, J., (1991). Quality Improvement through Standards, Stanley Thrones Ltd, London.

x. Dale, B. G., Boarden, R. J., and Lascelles, D. M., (1994). 'Total quality management: an overview', in Dale, B.G. (Ed.), Managing Quality, 2nd ed., Prentice-Hall, Hertsfordshire-London, pp. 3-40.

xi. Deming, W. E., (1982). Quality, productivity and competitive position, Massachusetts Institute of Technology, Cambridge.

xii. $\quad$ Deshpande, M., (2011). Human Resource Management in Printing Industry with Reference to Recruitment and Selection, Journal of Engineering Research and Studies, Vol. 2, No. 2, April-June, pp. 41-42.

xiii. Dimitrades, Z. S., (2000). 'Total Involvement in Quality Management, Team Performance Management', An International Journal, 6(7/8), pp. 117-121.

xiv. Djerdjour, M., \& Patel, R. (2000). Implementation of quality programmes in developing countries: a Fiji Islands case study. Total Quality Management, 11(1), 25-44.

xv. Gaither, N., (1994). Production and Operations Management, $6^{\text {th }}$ Edition, The Dryden Press, USA.

xvi. Godfrey, G., Dale, B., Marchington, M., and Wilkinson, A., (1997). 'Control: a contested concept in TQM research', International Journal of Operations and Production Management, Vol. 17, No. 6, pp. 558-573.

xvii. Grib, A. A. (1993). Quantum cosmology, the role of the observer, quantum logic. Quantum cosmology and the laws of nature: Scientific perspectives on divine action, 163-183.

xviii. Grib, B. J. P., (1993). A critical literature study and research conducted on selected South African companies. Stellenbosch: University of Stellenbosch.

xix. Hough, M., (2004). 'Updating our TQM thinking for a knowledge and service economy', Total Quality Management, Vol. 15, Nos. 5/6, pp. 753-791.

xx. Gryna, F. M., \&Juran, J. M. (1999). Quality and costs. New York: McGraw-Hill.

xxi. Kanji, G. K., and Asher, M., (1996). 100 Methods for Total Quality Management (New Delhi: Sage).

xxii. Kulkarni, S., (2005). 'Research and concepts: graph theory and matrix approach for performance evaluation of TQM in Indian industries', The TQM Magazine, Vol. 17, No. 6, pp. 509-526.

xxiii. Lancaster, L. C. (2005). Concrete vaulted construction in Imperial Rome: innovations in context. Cambridge University Press.

xxiv. Macdonald, J., and Piggott, J., (1990). Global Quality: The New Management Culture, Gold Arrow Publications Ltd, London.

xxv. Mani, T. P., Murugan, N., \&Rajendran, C. (2003). TQM is a must for success, but not sufficient for survival: A conceptual framework as contemplated in ancient Tamil literature in India. Total Quality Management \& Business Excellence, 14(4), 395-405

xxvi. Oakland, J., (2005). From quality to excellence in the $21^{\text {st }}$ Century, Total Quality Management, 16(8-9), pp. 10531060.

xxvii. Palacio, B. G., \&Vit, A., (2011). Graphic design referenced: A visual guide to the language, applications, and history of graphic design. Rockport Pub.

xxviii. Powell, T. C., (1995). 'Organisational alignment as competitive advantage', Strategic Management Journal, Vol. 13, No. 2, pp. 15-37.

xxix. Reger, R. K., Gustafson, L. T., Demarie, S. M., \&Mullane, J. V. (1994). Reframing the organization: Why implementing total quality is easier said than done. Academy of management Review, 19(3), 565-584. 
xxx. Romano, F., (2004). An investigation into printing industry trends (PICRM-2004-01), Rochester Institute of Technology, Printing Industry Center, Rochester, NY.

xxxi. Romano, P. (2003). Co-ordination and integration mechanisms to manage logistics processes across supply networks. Journal of purchasing and supply Management, 9(3), 119-134.

xxxii. Sebastianelli, R., \&Tamini, N. (1998). Barriers to TQM: A Class-Level Student Project. Journal of Education for Business, 73(3), 158-162.

xxxiii. Steingard D. S., and Fitzgibbons D. E., (1993). A postmodern deconstruction of total quality management (TQM), J. Org. Change Manage 6:27-42.

xxxiv. Stuelpnagel, T. R., (1993). 'Deja vu: TQM returns to Detroit and elsewhere', Quality Progress, Vol. 26, No. 9, pp. 91-95.

xxxv. Talha, M., (2004). 'Total quality management (TQM): an overview', Journal of the Bottom Line: Managing Library Finances, Vol. 17, No. 1, pp. 15-19.

xxxvi. Tamimi N., Sebastianelli R., (1998). The barriers to total quality management. Qual. Progr. 31(6): 57-60.

xxxvii. Van Seaton, H., (2010). 'The Organisational Cultural Perceptions of Implementing Six Sigma in a Government Enterprise', The Innovation Congress, Vol. 3, Issue 2, pp. 71-94.

xxxviii. Vuppalapati, K., Ahire, S. L., and Gupta, T., (1995). JIT and TQM: A case for joint implementation, International Journal of Operations and Production Management, 15(5), 84-94.

xxxix. Walsh, A., Hughes, H., and Maddox, D. P., (2002). 'Total quality management continuous improvement: is the philosophy a reality?',Journal of European Industrial Training, Vol. 26, No. 6, pp. 299-307.

xl. Yeung, V. W. S., and Armstrong, R.W., (2005). 'The management pattern of adopting TQM in Hong Kong companies', Journal of Total Quality Management, Vol. 16, No. 2, pp. 171-183.

xli. Zhang, Z. H., (2000). Implementation of total quality management: An empirical study of Chinese manufacturing firms. Unpublished Doctoral thesis, University of Groningen, Groningen, The Netherlands 